\title{
Penilaian Persediaan Barang Dagang berdasarkan SAK EMKM pada BUMDES Karya Maju Kec. Keluang Kab. Musi Banyuasin
}

\author{
Eka Sevita Mesta ${ }^{1)}$, Ryan Al Rachmat ${ }^{2)}$ \\ Politeknik Sekayu ${ }^{1), 2)}$ \\ Email: ekamesta86@gmail.com ${ }^{1)}$,ryan-alrachmat@hotmail.co.id ${ }^{2)}$
}

\begin{abstract}
The purpose of this study was to determine how the accounting treatment of inventory on the method of recording and assessing merchandise at Bumdes Karya Maju Kec. Kab. Musi Banyuasin with inventory observation periods in April and May 2020. In this study the researchers used a qualitative descriptive analysis method. The types of data used are primary and secondary. Where the primary data is in the form of interviews and field observations, while the secondary data is in the form of merchandise inventory data at Bumdes Karya Maju. Data collection methods used were interviews and field observations. The results showed that the method of recording and inventory of merchandise at Bumdes Karya Maju was not in accordance with SAK EMKM. Bumdes Karya Maju records merchandise inventory using an application called OMI, which has not applied any method in the application.
\end{abstract}

Keywords: Method of Recording, Merchandise, SAK EMKM

\section{Pendahuluan}

Perusahaan umumnya menjalankan kegiatan operasionalnya selain bertujuan mencari laba juga mempertahankan pertumbuhan perusahaan itu sendiri. Agar tujuan perusahaan tercapai, maka semua faktor- faktor produksi yang mempengaruhi hal tersebut diperhatikan dan diatur secara baik. Seluruh faktor-faktor produksi khususnya persediaan yang mempunyai peranan sangat penting dalam mencapai tujuan perusahaan. Oleh karena itu, persediaan memerlukan perencanaan, pengelolaan, dan pengawasan yang baik agar tidak terjadi kekurangan atau kelebihan persediaan yang dapat mengakibatkan terganggunya aktifitas perusahaan. Perencanaan, pengelolaan, dan pengawasan yang baik juga dilakukan agar kesalahan dalam mencatat dan menghitung nilai persediaan atau kecurangan-kecurangan yang mungkin akan terjadi dapat dicegah. Dengan sistem akuntansi yang baik penilaian terhadap persediaan akan menjadi suatu sarana untuk memberikan informasi yang dapat digunakan dalam evaluasi perusahaan serta sebagai alat untuk pengendalian intern yang baik.

Persediaan merupakan salah satu komponen penting untuk sebuah perusahaan, baik perusahaan kecil, menengah, maupun besar dalam menjalankan usahanya. Persediaan untuk UMKM diatur dalam Standar Akuntansi Keuangan Entitas Mikro Kecil dan Menegah (SAK-EMKM). Salah satu bentuk perusahaannya itu perusahaan dagang dengan kategori usaha mikro kecil dan menengah (UMKM) mempunyai persediaan. Menurut SAK EMKM persediaan adalah aset untuk dijual dalam kegiatan normal, dalam proses produksi untuk kemudiaan dijual atau dalam bentuk bahan atau perlengkapan untuk digunakan dalam proses produksi atau pemberiaan jasa. Terdapat dua metode 
penilaian persediaan yaitu metode Masuk Pertama Keluar Pertama (MPKP) dan metode rata-rata tertimbang (Average).

Akuntansi Keuangan Entitas Mikro, Kecil dan Menengah (SAK EMKM) tahun 2018 oleh Ikatan Akuntan Indonesia (IAI). Bumdes Karya Maju melakukan pencatatan persediaan dengan menggunakan aplikasi, namun didalam aplikasi tersebut belum menggunakan metode apapun. Hal ini dapat mengakibatkan lemahnya pengawasan terhadap persediaan barang dagang yang dimiliki oleh perusahaan, yang selanjutnya juga dapat mengakibatkan kesalahan dalam pencatatan dan perhitungan nilai persediaan barang dagang, serta peluang tindakan penyelewengan terhadap persediaan barang dagang semakin terbuka.

Melihat dari permasalahan tersebut metode pencatatan maupun penilaian persediaan sangat dibutuhkan untuk mengetahui stok persediaan yang tersisa digudang setiap saat, dan menghindari adanya kesalahan dalam pencatatan dan perhitungan nilai persediaan barang dagang, serta peluang tindakan penyelewengan terhadap persediaan barang dagang.

\section{Tinjauan Literatur}

\subsection{Persediaan}

Menurut Sujarweni (2019: 91) Persediaan barang dagangan adalah barang - barang yang di miliki perusahaan dan termasuk dalam akun aktiva lancar, sedangkan persediaan barang dagangan adalah barang - barang yang dimiliki perusahaan yang siap dijual dalam operasi perusahaan. Selain itu, Martani dkk (2016: 245) Persediaan merupakan salah satu asset yang sangat penting bagi suatu entitas baik bagi perusahaan ritel, manufaktur, jasa maupun entitas lainnya. sedangan Alexandri (2009) Persediaan adalah suatu aktiva yang meliputi barang-barang milik perusahaan dengan maksud untuk dijual dalam suatu periode usaha tertentu atau persediaan barang-barang yang masih dalam pengerjaan atau proses produksi ataupun persediaan bahan baku yang menunggu penggunaannya dalam pengerjaan atau proses produksi ataupun persediaan bahan baku yang menunggu penggunaannya dalam suatu proses produksi.

Berdasarkan SAK EMKM (2018), Persediaan adalah asset :

1. Untuk dijual dalam kegiatan normal

2. Dalam proses produksi untuk kemudian dijual; atau

3. Dalam bentuk bahan atau perlengkapan untuk digunakan dalam proses produksi atau pemberian jasa.

\subsection{Klasifikasi Persediaan}

Menurut Sujarweni (2019: 92) klasifikasi Persediaan barang dagangan terbagi menjadi beberapa kategori, tergantung pada jenis kegiatan perusahaan yaitu:

1. Perusahaan Jasa 
Perusahaan jasa tidak memiliki persediaan barang dagang karena yang dijual adalah jasa bukan barang.

2. Perusahaan dagang

Perusahaan dagang hanya mempunyai persediaan barang dagangan Contoh:

Dealer motor mempunyai persediaan barang dagangan berupa beberapa merek motor.

3. Perusahaan manufaktur/industry Perusahaan manufaktur/industri memiliki (dua) jenis persediaan yaitu:

a. Persediaan bahan baku,Barang-barang yang dibeli atau diperoleh dari sumber lain sebagai bahan mentah untuk selanjutnya diolah menjadi produk jadi. Dalam beberapa kasus, persediaan bahan baku yang digunakan di dalam proses produksi dapat berupa suku cadang yang diperoleh dari pihak lain.

b. Persediaan barang dalam proses Persediaan produk dalam proses biasanya meliputi barang- barang yang masih dalam proses "setengah jadi" Barangbarang dalam persediaan ini masih berada dalam proses pengerjaan yang memerlukan pengerjaan lebih lanjut sebelum barang itu dijual. Produk dalam proses, umumnya dinilai berdasarkan jumlah harga pokok bahan baku, biaya tenaga kerja langsung dan biaya overhead pabrik yang telah dikeluarkan atau terjadi sampai dengan tanggal tertentu.

\subsection{Jenis-jenis Persediaan}

Martini (2012: 143) jenis - jenis persediaan barang dagang mencakup sebagai berikut:

1. Persediaan Bahan Baku (material)

Merupakan persediaan dimana barang-barang yang digunakan adalah barang tahap awal dalam proses produksi.

2. Persediaan barang dalam proses (work in proses)

Merupakan persediaan dimana barang-barang yang digunakan adalah sebagai pelengkap dari bahan baku (material) dan untuk melanjutkan pada tahap barang jadi (finish good).

3. Persediaan barang jadi (finish good)

Merupakan persediaan dimana barang-barang yang ada adalah barangbarang yang sudah selesai diproduksi atau diolah dan siap untuk dijual atau yang sering disebut dengan finish good.

Stice (2009) Persediaan (atau persediaan barang dagang) secara umum ditujukan untuk barang-barang yang dimiliki oleh perusahaan dagang, baik berupa usaha grosir maupun ritel, ketika barang-barang tersebut telah dibeli dan ada pada kondisi siap untuk dijual. Sedangkan dalam perusahaan manufaktur, terdapat tiga jenis persediaan yaitu: 1 . Bahan baku (raw materials) adalah barang-barang yang dibeli untuk digunakan dalam proses produksi. 2. Barang dalam proses (work in process) terdiri atas bahan-bahan yang telah diproses, namun masih membutuhkan pengerjaan lebih lanjut sebelum dapat dijual. 3. Barang jadi (finished goods) adalah barang yang sudah selesai diproduksi dan menunggu untuk dijual. 


\subsection{Fungsi dan Prinsip-Prinsip Pengendalian Intern Persediaan}

Persediaan dapat memiliki berbagai fungsi dan prinsip-prinsip penting yang menambah fleksibilitas sebagai bagian utama dalam menjalankan kegiatan perusahaan. Menurut Sujarweni (2019 : 91), ada 5 (lima) fungsi untuk persediaan yaitu sebagai berikut:

1. Menghilangkan risiko keterlambatan datangnya barang atau bahanbahan yang dibutuhkan oleh perusahaan.

2. Menghilangkan risiko barang yang rusak.

3. Mempertahankan stabilitas operasi perusahaan atau menjamin kelancaran arus produksi.

4. Mencapai penggunaan mesin yang optimal. Memberikan pelayanan yang sebaik-baiknya bagi konsumen

Menurut Sujarweni (2019 : 92) ada 4 (empat) prinsip-prinsip pengendalian intern untuk persediaan yaitu meliputi:

1. Pemisahan tugas, penghitungan persediaan dilakukan oleh karyawan yang bukan bertugas mengawasi persediaan.

2. Penyelenggaraan pertanggungjawaban, masing-masing bagian dalam pengelolan persediaan wajib menggunakan otorisasi yang otentik.

3. Vertifikasi intern yang independen, penghitungan ulang persediaan oleh petugas yang lain dan dilakukan penandaan terhadap item barang persediaan. Penandaan hanya dilakukan sekali.

4. Prosedur pendokumentasian, menggunakan penandaan barang dengan dokumen yang sudah dinomori sebelumnya (prenumbered).

\subsection{Pengakuan dan Pengukuran Persediaan Barang Dagang}

Menurut Kartikahadi, dkk (2016: 329) Kepemilikan Persediaan terdiri menjadi beberapa bagian yaitu antara lain:

1. Barang dalam perjalanan

Barang-barang yang ada dalam laporan posisi keuangan masih dalam perjalanan menimbulkan masalah apakah masih milik penjual atau sudah pindah haknya pada pembeli. untuk mengetahui barang tersebut milik siapa, harus diketahui syarat pengiriman barang-barang tersebut

2. Penjualan angsuran (installment sales)

Dalam penjualan angsuran, hak atas barang tetap pada penjualan sampai seluruh harga jualnya dilunasi. Penjual akan melaporkan barang-barang tersebut dalam persediaanya dikurangi dengan jumlah yang sudah dibayar. Pembeli akan melaporkan barang-barang tersebut dalm persediaanya sejumlah barang yang sudah dibayarkan.

3. Barang-barang yang dipisahkan (segregated goods)

Sering terjadi suatu kontrak penjualan barang dalam jumlah besar sehinggah pengirimanya tidak dapt dilakukan sekaligus. Barang-barang yang dipisahkan tersendiri dengan maksud untuk memenuhi kontrakkontrak atau pesanan-pesanan walupun belum dikirim, haknya sudah berpindah kepada pembeli oleh karena itu pada tanggal penyusunan laporan keuangan jika ada barang-barang yang dipisahkan, harus 
dikeluarkan dari jumlah persediaan penjual dan dicatat sebagai penjualan. Begitu juga pembeli dapt mencatat pembelian dan menambah persediaan barangnya.

4. Barang-barang konsinyasi (consignment goods)

Dalam cara penjualan titipan, barang-barang yang dititipkan untuk dijual (dikonsinyasikan) haknya masih tetap pada yang menitipkan pada saat barang-barang tersebut dijual. Sebelum barang-barang tersebut dijual masih tetap menjadi persediaan pihak yang menitipkan (consigner). Pihak yang menerima titipan (consigner) tidak mempunyai hak atas barang-barang tersebut sehinga tidak mencatat barang-barang tersebut sebagai persediaanya. Apabila barang-barang tersebut sudah dijual maka yang menerima titipan membuat laporan kepada pihak yang menitipkan (consigner).

Menurut SAK EMKM (2018: 21) Pengakuan dan pengukuran persediaan yaitu:

1. Entitas mengakui persediaan ketika diproleh sebesar biaya perolehannya

2. Biaya perolehan persediaan mencakup seluruh biaya pembelian, biaya konversi, dan biayalainnya yang terjadi untuk membawa persediaan kekondisi dan lokasi siap digunakan

3. Teknik pengukuran biaya persediaan seperti metode biaya standar atau metode eceran demi kemudahan dapat digunakan jika hasilnya mendekati biaya perolehan

4. Entitas dapat memilih menggunakan rumus biaya masuk pertama keluar pertama (MPKP) atau rata-rata tertimbang dalam menentukan biaya perolehan persediaan

5. Jumlah persediaan yang mengalami penurunan atau kerugian, misalnya karena persediaan rusak atau using, diakui sebagai beban pada periode terjadinya penurunan atau kerugian tersebut.

Kieso dkk yang dikutip oleh Sujarweni (2019: 95) Pengakuan persediaan terbagi atas 2 (dua) kondisi yaitu sebagai berikut :

1. Perjanjian FOB Shiping Point, Menyatakan bahwa kepemilikan barang akan berpindah dari pembeli ke penjual saat barang berada dititik pengiriman (pelabuhan, atau masih digudang penjual). Sehingga, biaya pengiriman adalah tanggung jawab pembeli.

2. Perjanjian FO Destination, Menyatakan bahwa kepemilikan barang berpindah dari penjual ke pembeli saat barang tiba digudang pembell. Sehingga, biaya pengiriman adalah tanggung jawab penjual (supplier).

\subsection{Metode Pencatatan dan Penilaian Persediaan Barang Dagang}

Menurut Rudianto (2012: 222 ) untuk menghitung dan mencatat persediaan terdapat 2 (dua) metode yaitu sebagai berikut:

1. Metode fisik atau juga di sebut metode periodic adalah metode pengelolaan persediaan, dimana arus keluar masuknya barang tidak dicatat secara terinci sehingga untuk mengetahui nilai persediaan pada 
suatu saat tertentu harus melakukan penghitungan barang secara fisik (stock opname) di gudang.

2. Metode perpetual adalah metode pengelolaan persediaan dimana arus masuk dan arus keluar persediaan di catat secara terinci. Dalam metode ini setiap jenis persediaan di buatkan kartu stok yang mencatat secara rinci keluar masuknya barang digudang beserta harganya.

Perbedaan pencatatan persediaan dengan menggunakan system periodik dan sistem perpetual akan terlihat jelas berbeda, ketika suatu entitas menggunakan sistem perpetual, dan terdapat perbedaan antara pencatatan persediaan dengan perhitungan fisiknya, maka perusahaan harus melakukan pencatatan untuk menyesuaikan nilai pencatatan dengan nilai perhitungan fisiknya.

Menurut SAK EMKM (2018: 21) Penilaian Persediaan, yaitu :

Entitas mengakui persediaan ketika persediaan diperoleh sebesar biaya perolehannya, sedangkan biaya perolehan persediaan mencakup seluruh biaya pembelian, biaya konversi, dan biaya lainnya.

Teknik pengukuran biaya persediaan dapat menggunakan metode eceran jika hasilnya mendekati biaya perolehan. Penilaian persediaan entitas dapat memilih menggunakan rumus biaya MPKP atau masuk pertama keluar pertama atau rata-rata tertimbang dalam menentukan biaya perolehan persediaan.

Menurut Sujarweni (2019: 100) Mengatakan bahwa penilaian persediaan dibagi menjadi 4 (empat), tetapi yang sering digunakan dalam perhitungan persediaan antara lain :

1. Metode Fifo, Metode ini menyatakan bahwa persediaan dengan nilai perolehan awal (pertama) masuk akan dijual digunakan terlebih dahulu, sehingga persediaan akhir dinilai dengan nilai perolehan persediaan yang terakhir masuk (dibeli). Metode ini cenderung menghasilkan persediaan yang nilainya tinggi dan berdampak pada nilai aktiva perusahaan yang dibeli.

2. Metode Rata-rata (Average), Metode ini menyatakan nilai persediaan akhir akan menghasilkan antara nilai persediaan metode FIFO dan nilai persediaan LIFO. Metode biaya rata-rata tertimbang didasarkan pada asumsi bahwa seluruh barang tercampur, sehingga mustahil untuk menentukan barang mana yang terjual dan barang mana yang tertahan di persediaan.

Menurut Vinsen (2016: 14) mengjelaskan bahwa :

Metode eceran adalah metode penilaian persediaan akhir yang dihitung dengan membandingkan antara harga pokok barang dagang dengan harga jual ecerannya. Metode harga eceran digunakan dengan menggunakan dasar pembebanan dan perhitungan persentase terhadap harga pokok 
yang berbeda yaitu:

\begin{tabular}{|l|l|}
\hline Dasar Pembebanan Harga Pokok & \multicolumn{1}{|c|}{ Perhitungan Persentase Harga Pokok } \\
\hline MPKP (Fifo) & $\begin{array}{l}\text { Persediaan barang awal tidak dimasukan } \\
\text { dalam perhitungan persentase harga pokok }\end{array}$ \\
\hline Rata-Rata Tertimbang (Average) & $\begin{array}{l}\text { Persediaan awal dimasukan dalam perhitungan } \\
\text { persentase harga pokok }\end{array}$ \\
\hline $\begin{array}{l}\text { Harga Pokok atau Harga Pasar yang } \\
\text { Murah }\end{array}$ & $\begin{array}{l}\text { Penurunan harga neto tidak dimasukan dalam } \\
\text { perhitungan persentase harga pokok tetapi } \\
\text { ditambahkan pada penjualan }\end{array}$ \\
\hline MTKP $($ Lifo $)$ & $\begin{array}{l}\text { Kenaikan dan penurunan harga hanya } \\
\text { diperhitungkan pada barang yang dibeli dalam } \\
\text { periode }\end{array}$ \\
\hline
\end{tabular}

\section{Metode Penelitian}

Dalam melakukan pengumpulan data pada BUMDES Karya Maju Kec. Keluang, penulis melakukan beberapa metode pengumpulan data antara lain dengan metode observasi (Sugiyono (2018: 137), penulis melakukan pengamatan langsung ke obyek yang diteliti yaitu BUMDES Karya Maju Keluang. Selain itu jenis data yang digunakan dalam penelitian ini adalah data primer Sanusi (2016: 104) yang diperoleh melalui wawancara untuk lebih memperjelas data-data yang diperoleh dari teknik observasi yang dilakukan. di BUMDES Karya Maju Kec. Keluang adalah hasil wawancara dan observasi lapangan, yang meliputi lokasi wilayah, kondisi fisik usaha serta sarana dan prasarana lingkungan BUMDES Karya Maju Kec. Keluang tersebut, sedangkan data sekundernya berupa data statistik dan lainnya. Teknik analisis data dalam penelitiaan ini adalah teknik analisis Deskriptif Kuantitatif (Sugiyono (2018: 137) analisis digunakan atas penggunan motode penilaian persediaan pada Bumdes Karya Maju.

\section{Hasil dan Pembahasan}

Peneliti telah memperoleh data yang relevan dari Bumdes Karya Maju untuk kemudian data tersebut menjadi bahan untuk melakukan pencatatan dan penilaian persediaan sesuai dengan standar keuangan yang telah ditetapkan sebelumnya yaitu Standar Akuntansi Keuangan Entitas Mikro, Kecil dan Menengah. Beriku perhitungan akhir dari dua metode penilaian persediaan barang dagang pada Bumdes Karya Maju

Tabel 1.

Perhitungan Akhir Metode Penilaian Persediaan Barang Dagang pada Bumdes Karya Maju (MPKP)

\begin{tabular}{|c|c|c|c|r|r|}
\hline \multirow{2}{*}{$\begin{array}{c}\text { Nama } \\
\text { Produk }\end{array}$} & \multirow{2}{*}{ Bulan } & \multicolumn{4}{|c|}{ MPKP } \\
\cline { 3 - 5 } & & HPP (Rp) & Unit & Harga (Rp) & $\begin{array}{r}\text { Jumlah } \\
\text { (Rp) }\end{array}$ \\
\hline Marjan Melon 460 MI & April & $1.387 .154,-$ & 89 & $15.586,-$ & $1.387 .154,-$
\end{tabular}




\begin{tabular}{|c|r|r|r|r|r|} 
& & & & & \\
\hline & Mei & $1.652 .116,-$ & 35 & $15.586,-$ & $545.510,-$ \\
\hline Saldo Akhir & & $\mathbf{3 . 0 3 9 . 2 7 0 , -}$ & $\mathbf{3 5}$ & $\mathbf{1 5 . 5 8 6 , -}$ & $\mathbf{5 4 5 . 5 1 0 , -}$ \\
\hline Gulaku Gula Putih 1 Kg & April & $4.950 .400,-$ & 134 & $11.900,-$ & $1.594 .600,-$ \\
\hline & Mei & $1.332 .800,-$ & 138 & $11.900,-$ & $1.761 .200,-$ \\
\hline Saldo Akhir & & $\mathbf{6 . 2 8 3 . 2 0 0 , -}$ & $\mathbf{1 3 8}$ & $\mathbf{1 1 . 9 0 0 , -}$ & $\mathbf{1 . 7 6 1 . 2 0 0 , -}$ \\
\hline PSM Gula Premium 1 Kg & April & $6.973 .400,-$ & 150 & $11.900,-$ & $1.785 .000,-$ \\
\hline Saldo Akhir & Mei & $4.771 .900,-$ & 100 & $11.900,-$ & $1.190 .000,-$ \\
\hline Minyak Goreng & April & $8.320 .455,-$ & 49 & $23.705,-$ & $1.161 .545,-$ \\
\hline $\begin{array}{c}\text { Bimoli } \\
\text { REF2L }\end{array}$ & & & & & \\
\hline & Mei & $1.161 .545,-$ & 81 & $23.705,-$ & $1.920 .105,-$ \\
\hline Saldo Akhir & & $\mathbf{9 . 4 8 2 . 0 0 0 , -}$ & $\mathbf{8 1}$ & $\mathbf{2 3 . 7 0 5 , -}$ & $\mathbf{1 . 9 2 0 . 1 0 5 , -}$ \\
\hline Saldo Akhir & April & $3.564 .457,-$ & 27 & $21.939,-$ & $592.353,-$ \\
\hline GG Surya Filter 16's & Mei & $3.424 .193,-$ & 44 & $21.960,-$ & $900.360,-$ \\
\hline & & $\mathbf{6 . 9 8 8 . 6 5 0 , -}$ & $\mathbf{4 4}$ & $\mathbf{2 1 . 9 6 0 , -}$ & $\mathbf{9 0 0 . 3 6 0 , -}$ \\
\hline
\end{tabular}

Sumber : Data diolah, 2020

Tabel 2.

Perhitungan Akhir Metode Penilaian Persediaan Barang Dagang pada Bumdes Karya Maju (Average)

\begin{tabular}{|c|c|r|r|r|r|}
\hline \multirow{2}{*}{ Nama } & \multirow{2}{*}{ Bulan } & \multicolumn{4}{|c|}{ MPKP } \\
\cline { 3 - 6 } & & HPP (Rp) & Unit & Harga (Rp) & $\begin{array}{r}\text { Jumlah } \\
(\mathbf{R p})\end{array}$ \\
\hline Marjan Melon 460 Ml & April & 1.387 .154$, & 89 & $15.586,-$ & $1.387 .154,-$ \\
\hline & Mei & $1.652 .116,-$ & 35 & $15.586,-$ & $545.510,-$ \\
\hline Saldo Akhir & & $\mathbf{3 . 0 3 9 . 2 7 0 , -}$ & $\mathbf{3 5}$ & $\mathbf{1 5 . 5 8 6 , -}$ & $\mathbf{5 4 5 . 5 1 0 , -}$ \\
\hline Gulaku Gula Putih 1 Kg & April & $4.950 .400,-$ & 134 & $11.900,-$ & $1.594 .600,-$ \\
\hline & Mei & $1.332 .800,-$ & 138 & $11.900,-$ & $1.761 .200,-$ \\
\hline Saldo Akhir & & $\mathbf{6 . 2 8 3 . 2 0 0 , -}$ & $\mathbf{1 3 8}$ & $\mathbf{1 1 . 9 0 0 , -}$ & $\mathbf{1 . 7 6 1 . 2 0 0 , -}$ \\
\hline PSM Gula Premium 1 Kg & April & $6.973 .400,-$ & 150 & $11.900,-$ & $1.785 .000,-$ \\
\hline Saldo Akhir & Mei & $4.771 .900,-$ & 100 & $11.900,-$ & $1.190 .000,-$ \\
\hline Minyak Goreng & & $\mathbf{1 1 . 7 4 5 . 3 0 0 , -}$ & $\mathbf{1 0 0}$ & $\mathbf{1 1 . 9 0 0 , -}$ & $\mathbf{1 . 1 9 0 . 0 0 0 , -}$ \\
\hline $\begin{array}{l}\text { Bimoli } \\
\text { REF2L April }\end{array}$ & $8.320 .455,-$ & 49 & $23.705,-$ & $1.161 .545,-$ \\
\hline Saldo Akhir & Mei & $1.161 .545,-$ & 81 & $23.705,-$ & $1.920 .105,-$ \\
\hline & & $\mathbf{9 . 4 8 2 . 0 0 0 , -}$ & $\mathbf{8 1}$ & $\mathbf{2 3 . 7 0 5 , -}$ & $\mathbf{1 . 9 2 0 . 1 0 5 , -}$ \\
\hline
\end{tabular}




\begin{tabular}{|c|c|c|c|r|r|} 
GG Surya Filter 16's & April & $3.564 .457,-$ & 27 & $21.939,-$ & $592.353,-$ \\
\hline & Mei & $3.424 .193,-$ & 44 & $21.960,-$ & $900.360,-$ \\
\hline Saldo Akhir & & $\mathbf{6 . 9 8 8 . 6 5 0 , -}$ & $\mathbf{4 4}$ & $\mathbf{2 1 . 9 6 0 , -}$ & $\mathbf{9 0 0 . 3 6 0 , -}$ \\
\hline
\end{tabular}

Sumber : Data diolah, 2020

Dari kedua perhitungan tersebut, belum dapat dilihat perbedaan nilai persediaan akhir antara kedua metode harga eceran rumus Metode MPKP (Masuk Pertama-Keluar Pertama) dan Rata-rata Tertimbang. Karena harga jual setiap produk tidak mengalami perubahan. Namun, perusahaan sebaiknya menggunakan metode harga eceran rumus MPKP (Masuk Pertama-Keluar Pertama) dalam melakukan perhitungan penilaian persediaan barang dagang, karena nilai persediaan akhir menggunakan rumus MPKP biasanya akan menghasilkan harga pokok penjualan yang kecil sehingga laba kotor yang diperoleh menjadi besar.

Penggunaan metode dalam penilaian persediaan barang sangat berpengaruh terhadap laporan keuangan, yaitu berpengaruh pada nilai persediaan akhir di laporan posisi keuangan dan harga pokok penjualan di laporan laba rugi. Jika metode yang digunakan dalam penilaian persediaan barang dagang tidak tepat, maka nilai persediaan akhir di laporan posisi keuangan tidak mencerminkan nilai yang sebenarnya. Begitu juga dengan harga pokok penjualan di laporan laba rugi, jika metode yang digunakan dalam penilaian persediaan barang dagang tidak tepat maka harga pokok penjualan pada laporan laba rugi tidak mencerminkan nilai yang sebenarnya.

Berdasarkan hasil analisis penilaian persediaan barang dagang dengan metode harga eceran rumus MPKP (Masuk Pertama-Keluar Pertama) dan rumus Rata-rata Tertimbang, maka dapat diketahui harga pokok penjualan yang sebenarnya untuk masing-masing produk. Berikut disajikan perbandingan hasil laba kotor rumus MPKP (Masuk Pertama-Keluar Pertama) dan rumus Rata-rata Tertimbang, yaitu sebagai berikut :

Tabel 3.

Perbandingan Hasil Laba Kotor Bumdes Karya Maju

\begin{tabular}{|c|c|c|c|c|c|c|c|}
\hline \multirow{3}{*}{ Nama Barang } & \multicolumn{6}{|c|}{ Hasil Perhitungan } & \multirow{3}{*}{$\begin{array}{r}\text { Selisih } \\
\text { (Rp) }\end{array}$} \\
\hline & \multicolumn{3}{|c|}{$\begin{array}{c}\text { MPKP } \\
\text { (Masuk Pertama Keluar Pertama) }\end{array}$} & \multicolumn{3}{|c|}{$\begin{array}{c}\text { Rata-Rata Tertimbang } \\
\text { (Average) }\end{array}$} & \\
\hline & $\begin{array}{c}\text { Penjualan } \\
\text { (Rp) }\end{array}$ & HPP (Rp) & $\begin{array}{l}\text { Laba } \\
\text { Kotor } \\
\text { (Rp) }\end{array}$ & $\begin{array}{c}\text { Penjualan } \\
\text { (Rp) }\end{array}$ & HPP (Rp) & $\begin{array}{c}\text { Laba } \\
\text { Kotor } \\
\text { (Rp) }\end{array}$ & \\
\hline $\begin{array}{l}\text { Marjan Melon } \\
460 \mathrm{Ml} \\
\text { Gulaku Gula }\end{array}$ & \begin{tabular}{|l|}
$3.705 .000,-$ \\
$8877000-$
\end{tabular} & \begin{tabular}{|c|}
$\begin{array}{c}3.039 .270 \\
-\end{array}$ \\
6.402 .200 \\
\end{tabular} & $\frac{665.730,-}{2474800-}$ & $\frac{3.705 .000,-}{8877000-}$ & \begin{tabular}{|l}
$3.039 .270,-$ \\
$6.402 .200-$
\end{tabular} & $\begin{array}{r}665.73 \\
2474.80\end{array}$ & \\
\hline
\end{tabular}




\begin{tabular}{|c|c|c|c|c|c|c|c|}
\hline $\mathrm{ti}$ & & & & & & & \\
\hline $\begin{array}{ll}\text { PSM Gula } & \text { Gremium } 1 \mathrm{Kg}\end{array}$ & 13.975.500, & $\begin{array}{c}9.960 .300, \\
-\end{array}$ & 4.015.200,- & 13.975.500, & $9.960 .300,-$ & 4.015.200,- & \\
\hline $\begin{array}{l}\text { Bimoli } \\
\text { Minyak } \\
\text { Goreng }\end{array}$ & $11.400 .000,-$ & $\begin{array}{c}9.482 .000 \\
-\end{array}$ & $1.918 .000,-$ & 11.400.000, & $9.482 .000,-$ & 1.918.000,- & \\
\hline $\begin{array}{l}\text { GG Surya } \\
\text { Filter 16's }\end{array}$ & 7.731.100,- & $\begin{array}{c}6.922 .770, \\
-\end{array}$ & 808.330,- & 7.731 .100 & $6.922 .862,-$ & $808.238,-$ & 92 \\
\hline
\end{tabular}

Sumber: Data diolah, 2020

Berdasarkan tabel perbandingan di atas, dapat dilihat perbedaan hasil laba kotor menurut metode harga eceran rumus MPKP (Masuk Pertama-Keluar Pertama) dan rumus Ratarata Tertimbang (Average). Untuk produk Marjan Melon 460 Ml, Gulaku Gula Putih 1 Kg, PSM Gula Premium $1 \mathrm{Kg}$, Bimoli Minyak Gpreng REF2L tidak memiliki selisih atau perbedaan, dikarenakan tidak mengalami perubahan harga. Namun, pada produk GG Surya Filter 16's pada metode MPKP memiliki HPP sebesar Rp. 6.922.770, sedangkan metode Average sebesar Rp. 6.922.862, sehingga keduanya memiliki selisih sebesar Rp. 92.

Berdasarkan hasil analisis secara keseluruhan, penggunaan metode harga eceran rumus MPKP (Masuk Pertama Keluar Pertama) menghasilkan laba kotor yang lebih besar dibandingkan dengan menggunakan rumus Rata-rata Tertimbang (Average). Oleh karena itu, perusahaan sebaiknya menggunakan metode harga eceran rumus MPKP (Masuk Pertama Keluar Pertama) dalam melakukan penilaian persediaan barang dagang.

\section{Kesimpulan dan Saran}

\subsection{Kesimpulan}

1. Bumdes Karya Maju Kec. Keluang belum menerepakan penilaian persediaan barang dagang karena perusahaan menggunakan aplikasi untuk melakukan pencatatan persediaan, dan belum sesuai dengan SAK EMKM tahun 2018.

2. Penerapan Penilaian Persediaan Bumdes Karya Maju yang disusun berdasarkan SAKEMKM menyajikan dua rumus berdasarkan metode harga ecer yaitu Masuk Pertama Keluar Pertama (MPKP) dan Rata-rata Tertimbang (Average). Berdasarkan kedua metode tersebut dapat disimpulkan bahwa metode MPKP menghasilkan Harga Pokok Penjualan lebih kecil dibandingkan dengan metode Rata-rata Tertimbang. Sedangkan Laba Kotor yang dihasilkan pada metode MPKP lebih besar dibanding dengan metode Rata-rata Tertimbang.

\subsection{Saran}

1. Bumdes Karya Maju Kec. Keluang sebaiknya menerapkan metode penilaian persediaan barang dagang berdasarkan SAK EMKM tahun 2018 agar harga pokok produk dan nilai persediaan akhir barang dapat menjelaskan nominal yang sebenarnya.

2. Dalam melakukan penilaian persediaan barang dagang, perusahaan sebaiknya menggunakan metode harga eceran rumus MPKP (Masuk Pertama-Keluar Pertama). Dengan menggunakan metode harga eceran rumus MPKP dalam menilai persediaan 
barang dagang, maka nilai persediaan akhir pada laporan posisi keuangan dan harga pokok penjualan pada laporan laba rugi dapat mencerminkan nilai yang sebenarnya.

Selain itu dari hasil analisis yang telah dilakukan, penggunaan metode eceran rumus MPKP (Masuk Pertama-Keluar Pertama) dapat menghasilkan laba kotor yang lebih besar.

\section{Referensi}

Alexandri, Moh., Benny. 2009. Manajemen Keuangan Bisnis Teori dan Soal. Bandung: Alfabeta.

Baridwan, Zaki. 2013. Intermediate Accounting. Yogyakarta : BPFE-Yogyakarta.

Kartikahadi, Hans, dkk. 2016. Akuntansi Keuangan Berdasarkan SAK Berbasis IFRS. Jakarta Selatan : Salemba Empat.

Martani, Dwi dkk. 2016. Akuntansi Keuangan Menengah Berbasis PSAK. Jakarta: Salemba Empat.

Rudianto. 2012. Pengantar Akuntansi (Konsep \& Teknik Penyusunan Laporan Keuangan). Jakarta : Erlangga.

Sanusi, Anwar. 2016. Metodologi Penelitian Bisnis. Jakarta : Salemba Empat.

Stice, James D. \& Earl K., Stice. 2009. Akuntansi Keuangan Intermediate Accounting. Jakarta: Salemba Empat.

Sugiyono. 2018. Metode Penelitiaan Kuantitatif, Kualitatif dan R\&D. Bandung : Alfabeta.

Sujarweni. 2019. Pengantar Akuntansi 2. Yogyakarta : PT. Pustaka Baru.

SAK-EMKM. 2018. Standar Akuntansi Keuangan Entitas Mikro, Kecil, dan Menengah. Jakarta : Ikatan Akuntan Indonesia.

Vinsen. 2016. Penilaian Persediaan dengan Metode Taksiran Harga Eceran. Surabaya : Makalah (online). (https://www.coursehero.com, diakses 20 juli 2020) 